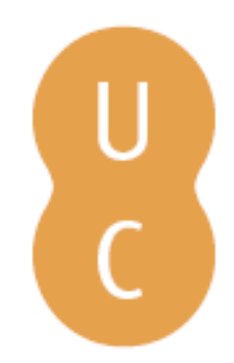

\title{
Rompalina
}

\section{Revistas ilustradas a serviço da República: imagem, literatura e técnica}

Autor(es): $\quad$ Martins, Ana Luiza

Publicado por: Imprensa da Universidade de Coimbra

URL

persistente: URI:http://hdl.handle.net/10316.2/30915

DOI: $\quad$ DOI:http://dx.doi.org/10.14195/978-989-26-0497-8_6

Accessed : $\quad$ 26-Apr-2023 12:52:09

A navegação consulta e descarregamento dos títulos inseridos nas Bibliotecas Digitais UC Digitalis, UC Pombalina e UC Impactum, pressupõem a aceitação plena e sem reservas dos Termos e Condições de Uso destas Bibliotecas Digitais, disponíveis em https://digitalis.uc.pt/pt-pt/termos.

Conforme exposto nos referidos Termos e Condições de Uso, o descarregamento de títulos de acesso restrito requer uma licença válida de autorização devendo o utilizador aceder ao(s) documento(s) a partir de um endereço de IP da instituição detentora da supramencionada licença.

Ao utilizador é apenas permitido o descarregamento para uso pessoal, pelo que o emprego do(s) título(s) descarregado(s) para outro fim, designadamente comercial, carece de autorização do respetivo autor ou editor da obra.

Na medida em que todas as obras da UC Digitalis se encontram protegidas pelo Código do Direito de Autor e Direitos Conexos e demais legislação aplicável, toda a cópia, parcial ou total, deste documento, nos casos em que é legalmente admitida, deverá conter ou fazer-se acompanhar por este aviso.

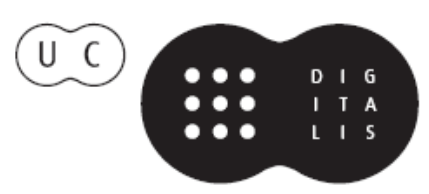


Armando Malheiro da Silva

Maria Luiza Tucci Carneiro

Stefano Salmi

Coordenação

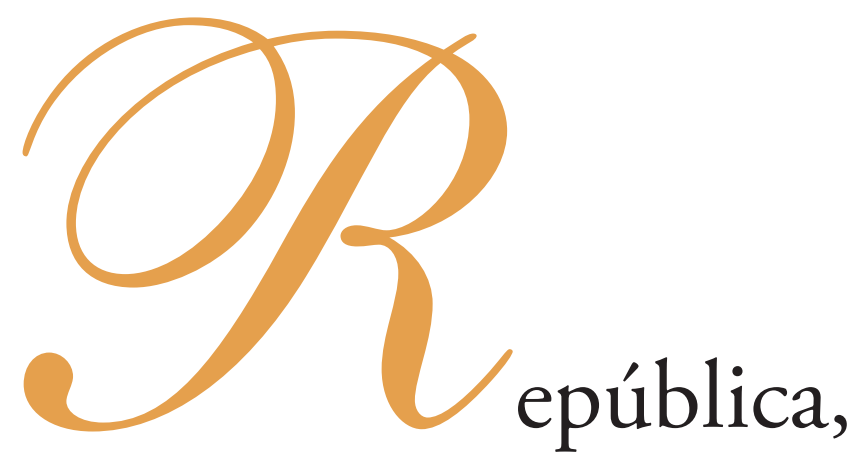

Republicanismo

e Republicanos

Brasil • Portugal • Itália 


\section{Ana Luiza Martins}

\section{REVISTAS ILUSTRADAS A SERVIÇO DA REPÚBLICA. IMAGEM, LITERATURA E TÉCNICA}

Imprensa e República: um roteiro conjugado

A idéia de República, presente no ideário das elites letradas do Brasil desde a Colônia, encontrou na imprensa seu veículo preferencial, instrumento decisivo para sua propagação, ainda que em território de atraso cultural e fracas letras. Antes mesmo da tardia chegada dos prelos na América portuguesa, em 1808, tipografias clandestinas e impressos episódicos estiveram a serviço dos movimentos insurrecionais contra a Metrópole, divulgando as idéias liberais em curso. A República era uma delas.

Não foi diferente às vésperas da Independência. Antes mesmo das Cortes aprovarem o fim da censura, em 1821, editava-se na Bahia a gazeta Idade D'Ouro no Brasil (1811-1819), de Silva Serva e por volta de 1815, no Recife, Rodrigo Catanho importava uma tipografia, que seria de muita utilidade na Revolução Pernambucana, de 1817, de forte cunho republicano. Na qualidade de abrigo literário, mas também dotadas de laivos políticos, editaram-se nesta década, as duas revistas inaugurais do Brasil: na Bahia, As Variedades ou Ensaios de Literatura (1812); no Rio de Janeiro, O Patriota, jornal literário, político e mercantil (1813), trazendo no título termo proscrito na época, de cunho revolucionário, suscitando o sentimento nativista.

Liberada a censura, seguiu-se o jornalismo apaixonado das campanhas liberais, definidor de práticas e posturas que subsidiaram o processo de 
Independência do Brasil. Através daquelas folhas, gazetas, pasquins e panfletos, de duração efêmera, delinearam-se linhas editoriais como expressão de grupos políticos inflamados, registros do jornalismo polêmico e contestador da emergência da nação, muitos deles de cunho republicano. Das folhas políticas de nomes curiosos das vésperas da Independência - Revérberos, Malaguetas, Macacos e Papagaios - chegou-se àquelas imediatamente posteriores - as Sentinelas e Auroras onde se alternaram momentos de altivez, de fala solene, com outros de achincalhes verbais, termos chulos, "insultos impressos" decisivos no processo emancipador ${ }^{179}$.

Esta linguagem textual engataria com aquela ilustrada quando, junto à palavra, coube à imagem reproduzir o cotidiano e criticá-lo até de forma perversa.

\section{"Rindo se criticam os costumes"}

A comunicação pelo humor e pela caricatura ganhou relevo no país avesso à propagação da palavra escrita. A válvula de escape do bumor funcionou como antídoto contra a censura vigente, bem como o desenho, como expressão plausível de fácil e imediata comunicação.

Da oralidade divertida registrada na Colônia, chegou-se rapidamente à proliferação do desenho satírico do papel impresso da Regência, constituindo-se o traço caricaturado numa das linguagens de maior aceitação do Brasil. Isso ocorreu não por obra imediata da introdução dos prelos, em 1808, mas por arte dos tantos transplantes que pontuaram nosso ansioso e desesperado ajuste com o tempo cultural dos países ditos "adiantados", sobretudo, quando ateliês e/ou oficinas litográficas, surgindo como um mercado, subsidiaram as ilustrações iniciais.

O recurso da ilustração periódica também vinha na esteira de um modismo - aquele dos jornais caricatos que faziam sucesso na Europa. Em particular na França, onde o talento do caricaturista Honoré Daumier (1808-1879) imprimia em desenho as contradições e ironias da Paris pós-revolução burguesa

\footnotetext{
${ }^{179}$ Ver LUSTOSA, Isabel - Insultos impressos. A guerra dos jornalistas na Independência. 1821 -1823. São Paulo: Companhia das Letras, 2000.
} 
de 1830, num quadro de barateamento das ilustrações e multiplicação das folhas periódicas, espaços de liberdade e recreação.

Não seria diferente no Brasil, onde os modismos não tardavam a chegar. Desta vez, através de Manoel de Araújo Porto-Alegre (1806 -1879), talentoso pintor brasileiro que vivenciou a experiência em Paris, transplantando-a para o Rio de Janeiro. Há consenso em atribuir-lhe a veiculação da primeira caricatura no Brasil, impressa no Jornal do Comércio (1827), no ano de 1837. O tema? Uma cena de suborno, metáfora prenunciadora e recorrente até nossos dias da corrupção no país. Em 1844 lançou um dos primeiros jornais de caricatura do Brasil Independente, irônico e engraçado: A Lanterna Mágica — Periódico Plástico-Filosófico.

Não tardou que outros impressores, ilustradores e jornalistas de talento investissem no gênero, que se propagou por todo o Império como uma das formas de expressão mais festejadas do período, sobretudo pelos artistas estrangeiros, que sentiram no jovem país oportunidades para seus talentos. A começar pelo alemão Henrique Fleuiss, que aqui chegou em 1853, e como tipógrafo imperial produziu um dos raros periódicos de caricaturas favoráveis ao Monarca: A Semana Ilustrada (1860).

Data, porém, de 1854 a chegada do piemontês Angelo Agostini, opondo-se frontalmente à Monarquia. Passara a adolescência em Paris e politizado, talentoso, perspicaz, ousado, produziu o legado mais expressivo e formador de escola. De sua produção paulista registram-se O Diabo Coxo e O Cabrião, ambos de 1866, que tinham a Igreja como alvo sistemático. No Rio de Janeiro, estreou com O Arlequim (1867), atuou na Vida Fluminense (1868) e em 1876 iniciou sua vitoriosa Revista Ilustrada, em sociedade com Paul Théodore Robin, proprietário de qualificada oficina a vapor. Ali investiu todo seu talento e obstinação no combate ao regime, um dos libelos mais contundentes a favor da República, em pleno Império. Em 1874, o italiano Luigi Borgomainerio, diretor artístico do importante jornal humorístico italiano Spirito Foletto; em 1875, era a vez do português Rafael Bordalo Pinheiro, crítico mordaz e inspirado. Todos eles, mordazes contra o regime e propagandistas da República.

Valeram-se da pedra litográfica como suporte técnico e da crítica política como mensagem de comunicação. A litografia permitia a reprodução de custo baixo no território sem tradição de prelos, e a mensagem se infiltrava decisivamente em meio à sociedade reprimida pela Igreja, pelo Estado e pelo regime 
escravo. As três temáticas — Igreja, Governo e Escravidão — foram recorrentes no lápis de sebo de carneiro daqueles caricaturistas, que investiram especialmente contra a benevolência dos títulos nobiliárquicos, o obscurantismo religioso, a presença retrógrada da instituição escrava, as crises ministeriais. Nessa produção, em meio às nuanças em preto e branco, surgia o monarca D. Pedro II, figura caricata preferencial do período e em negando a Monarquia, se exaltava a República.

Assim, na imprensa que se construía à sombra do modelo francês — inclusive adotando o folhetim de pé de página — foram colocadas estorietas ilustradas não menos rocambolescas, que introduziram no Brasil a caricatura como narrativa, recurso poderoso que educava, fazia rir, enfeitava e potencializava uma iniciante imprensa das letras.

Rede urbana e folhas volantes na esteira do café

Entre a imagem que fazia rir e o texto pomposo dos bacharéis, ao alcance de poucos, documentava-se o remanso do Império, com poucas cidades, seguindo curso pacato de uma economia fechada e dependente em tudo do comércio externo. Essa situação mudaria, em parte, na segunda metade do século XIX, ao compasso de nossa balança comercial, onde o café, desde 1830 tornara-se produto de exportação destacado. Em seu rastro, sobrevieram transformações importantes. A primeira delas foi a implantação da ferrovia, inaugurada no Rio de Janeiro, em 30 de Abril de 1854, quando o trem figurou como móvel transformador que imprimiu outro ritmo ao Império, marco também do crescimento da rede urbana, da circulação das idéias e do desenvolvimento da imprensa no país.

A agilização da notícia, agora transportada pelo trem, dava significado para uma imprensa que se expandia por regiões de maior população, especialmente pelo fluxo imigratório para fazendas de café do interior. Na seqüência, a melhoria técnica advinda da introdução do telégrafo e do cabo submarino, passaram a dar sustentação à produção do jornal, transformando-o em negócio potencialmente rentável. Muitas gráficas artesanais surgiram nos centros urbanos nascidos à sombra do café, dando origem ao jornal do interior das províncias, iniciativa de agentes sociais anônimos, acreditando na ação modificadora dos prelos. 
No último quartel do século XIX, pelas folhas da Corte e mesmo do interior, o questionamento do sistema se acirrou, centrado em três temas recorrentes: a campanha da abolição; as crises entre a Igreja e o Estado (a chamada Questão Religiosa) e a insatisfação dos militares com o Império (a chamada Questão Militar). Todas elas foram habilmente trabalhadas pelos jornalistas de plantão, contrapondo uma Monarquia que sufocava à idéia de uma República que libertava.

\section{Imprensa propagandística}

Em torno de 1870 gravitam fatos decisivos para o curso histórico do país. $\mathrm{Na}$ sede da Corte, fundava-se o Partido Republicano, criava-se o jornal A República e lança-se um Manifesto Republicano, assinado pelos "bacharéis-jornalistas" Quintino Bocaiúva, Saldanha Marinho e Salvador de Mendonça, nomes que se ligariam à história da imprensa do país.

O ideal republicano - acalentado no Brasil desde o século XVIII — retornava sob a pena dos jornalistas, como programa de partido, pela criação de uma imprensa partidária. A despeito desta propaganda republicana, até por volta dos anos de 1870 e 1880, reunir poucos partidários no país, a idéia de República foi liderada e difundida por uma imprensa vivaz, na qual militaram estudantes, jovens oficiais, cafeicultores do sudeste e, em especial, os quadros do PRP (Partido Republicano Paulista).

Em São Paulo, o Correio Paulistano convertia-se em órgão liberal, agasalhando atos oficiais dos republicanos. A Gazeta de Campinas (1869) abrigou ninho de republicanos. A criação do jornal A Província de São Paulo (1875), a despeito das bases de sua organização enfatizarem que o jornal "não é órgão de partido algum, nem advoga interesse de qualquer deles", levou seus acionistas a divulgar atos oficiais do PRP; inclusive um Boletim Republicano, redigido por Rangel Pestana e Américo de Campos, políticos envolvidos com a causa. Republicano também o Diário Popular (1884), embora se declarasse voltado apenas aos "interesses municipais".

Datam daquela época as inúmeras pequenas folhas de proposta republicana que se espalharam pelas cidades alinhadas no roteiro do café, precárias na 
fatura e de curta duração, mas de efetiva circulação. Em campanha orquestrada - em geral presidida por membros das Lojas Maçônicas - propagavam as Luzes, veiculavam a criação de escolas de primeiras letras, escolas noturnas para alfabetização de adultos e escravos, bibliotecas populares e pregavam a República, tentativas preliminares de construção do cidadão ${ }^{180}$.

Contudo, apesar das vozes republicanas dissonantes, a imprensa do Império como um todo guardou forte orientação monarquista, com manifestações de jornalismo áulico de exaltação ao Imperador, até às vésperas do golpe militar.

\section{Vivas à República!}

A campanha republicana vinha crescente, mas sua Proclamação pelos militares, no raiar da madrugada de 15 de Novembro, surpreendeu a muitos. Ato contínuo à Proclamação, a imprensa de caráter monarquista, transformou-se em imprensa republicana. As páginas de comemoração do 15 de Novembro de 1889, da Revista Ilustrada, de Angelo Agostini, fecham um ciclo e permitem uma conclusão: parte daquela história fora feita e contada nas páginas periódicas da imprensa política - literária em que surgiu o jornalismo no Brasil.

Cumprira-se a fase heróica do jornalismo brasileiro, arrebatado pelos ideais de gerações que fizeram da imprensa o instrumento eficaz de crítica ao regime, arauto quase exclusivo das forças descontentes. Seu principal agente - o jornalista egresso das Faculdades de Direito do País - trazia na bagagem o jornalismo de combate, conjugando a causa política, a linguagem empolada e os compromissos literários. Nascia daí a construção da mística republicana como proposta de modernidade. Como diferencial do período - em que o anonimato também foi uma constante - registrava-se a ampla liberdade de expressão, propulsora daquela rica produção, de credos diversos e ensaios múltiplos, em busca do ideal maior: a construção da nação.

\footnotetext{
${ }^{180}$ MARTINS, Ana Luiza - Gabinetes de Leitura da Província de São Paulo: a pluralidade de um espaço esquecido. São Paulo: Mestrado História USP, 1990.
} 


\section{Sedutoras matrizes francesas}

$\mathrm{Na}$ nova Ordem a circulação de revistas se intensificou. Um segmento importante foi representado pelas revistas de fatura francesa, algumas delas a serviço da propaganda republicana, voltadas para sua consolidação. Sabe-se que O Diabo Coxo e o Cabrião, de Angelo Agostini, considerados os primeiros periódicos ilustrados paulistas, já traziam no título a marca francesa. Mas, na São Paulo da República, o campo das revistas francesas ampliou-se, definido por interesses da Capital do Café, agora atraente empório comercial da América do Sul. A população quadruplicara, saltando de 64. 934 habitantes em 1890 para 239. 820 habitantes em 1900; a população estrangeira tomara vulto singular, configurada não apenas pela massa imigrante, mas por estrangeiros investidores, representantes de firmas européias e norte-americanas, e mesmo de particulares, que conformavam parte da população leitora, ávida de informação. Com essa demanda, proliferaram as revistas estrangeiras, de feitura superior, apoiadas em capitais de fora. Sofisticaram-se na qualidade do papel, através do corpo de colaboradores, circulando no Brasil e exterior, especialmente em territórios de língua portuguesa. Algumas delas vinham bilíngües, para alcance de maior público. Sua aquisição, em geral se dava por assinatura, às quais já estavam familiarizados membros da elite afrancesada do País. Produzir revistas sobre o Brasil passou a ser um bom negócio, especialmente para os franceses.

De Paris para o Brasil, via Bordéus: comércio, política e frivolidades em couché

A luxuosa Revue du Brésil ${ }^{181}$, sob a divisa Labor Omnia Vincit, de 1896, pode ser tomada como exemplo inaugural. Com sede em Paris, sob direção do jornalista italiano Alexandre D' Atri, bimensal, redigida em três línguas - francês, italiano e espanhol - confirmava o significativo público leitor estrangeiro, interessado em informações sobre o Brasil.

O Brasil republicano começava a aparecer na geografia comercial e interessar ao mundo. Especialmente aos países europeus latinos, que despertavam para

\footnotetext{
${ }^{181}$ Revue du Brésil. Paris: no 1 (nov. 1896).
} 
a potencialidade de novo mercado, num país de formidável extensão territorial, recebendo contingentes populacionais com a imigração, livre das amarras da escravidão, da religião católica obrigatória, vivenciando o liberalismo econômico.

Em momento em que grupos remanescentes monarquistas ainda se debatiam pela sua causa, a Revue du Brésil colocava-se como propagandista da República, quase uma porta-voz jacobina do período. Insistindo no anacronismo da Monarquia e na fábula que se tornara o direito divino, veiculava artigos denunciando conspirações monarquistas. Em 1897, estampava telegrama de Campos Salles, anunciando o fechamento do Centro Monarquista de São Paulo como medida de ordem pública.

Mas, o caráter comercial da revista era mais relevante. Seu editor, hábil negociante, divulgou a "jovem República", veiculando suas possibilidades de investimento. Ardilosamente, vendia uma imagem promissora e atraente do país, contrapondo o "caráter pacífico" da transição política à belicosidade e agitação das demais repúblicas latinas, marcadas por convulsões freqüentes. E mais, São Paulo era focalizado como "o mais promissor Estado da Federação".

O panorama rico de informes que a Revue du Brésil legou do país nesta década republicana - que deve ser visto com reservas - decorria da qualidade do corpo de colaboradores, os melhores literatos e jornalistas da nascente República. Mas, com exceção da seção política, assumida por republicanos históricos, os demais não se destacavam por partidarismo extremado. Afonso Arinos, inclusive, não disfarçava a simpatia monárquica.

Data deste mesmo ano de 1896, igualmente via Paris e voltada para o mesmo público alvo, a já mencionada Revista Moderna, ousada iniciativa do brasileiro Martinho Botelho. Impressa em português, trazia capa a cores, papel couché, resultando em publicação de nível elevado, sobretudo, pela colaboração de Eça de Queiróz e Eduardo Prado. Ao contrário, porém, da Revue du Brésil, o editor da Revista Moderna veiculou intensamente as proezas das casas reais européias, abrigando em seu corpo editorial o monarquista intransigente, Eduardo Prado.

Em 1901, veio a público a revista Ilustração Brasileira ${ }^{182}$, trazendo numeração de páginas seqüencial, induzindo à formação da coleção. Com escritório

\footnotetext{
${ }^{182}$ Ilustração Brasileira. Bordéus, Paris: ano I (1 ago. 1901). O último número conhecido é o nº 12, de Julho de 1902.
} 
em Paris, era impressa em Bordéus, porta de entrada e saída de brasileiros na Europa. Atendia a essa valiosa fatia de mercado presidida pelas oportunidades de negócios que se anunciavam em território brasileiro, agora republicano, divulgado como promissor.

Mais do que reproduzir a original Illustration Française, vinha confirmar a voga do periodismo francês das revistas ilustradas, fórmula efetivamente apreciada no Brasil, indiciando um espectro de leitor de elite, com potencial econômico para seu consumo.

$\mathrm{Na}$ mesma linha das publicações anteriores, reeditou o discurso do progresso, creditando o Brasil como alvo de negócios promissores. Investindo em homenagens a republicanos ilustres e tradicionais monarquistas, a revista não se descuidou de agradar ao segmento economicamente potencializado, vindo ao encontro das suas demandas, através de um espectro temático amplo, fórmula ideal para atingir um público variado. Ali constavam também as frivolidades do mundo da moda, embaladas em couché, que seguiam para pontos diversos do País, com agentes na Bahia, Minas Gerais, Rio Grande do Sul, Pernambuco. Tudo indica que São Paulo centralizava sua representação no Brasil, pois ao lado de reclames de firmas francesas, constavam apenas anunciantes da praça paulistana.

Em 1904, o comerciante francês Charles Hu, Conselheiro do Comércio Exterior da França, comerciante de vinhos e exportador de conservas alimentares, lançava a revista France-Brésil, revue mensuelle de propagande industrielle et commerciale. Nela, acima de tudo, veiculava a imagem da São Paulo do Progresso. Aperfeiçoando o gênero de periódico comercial ilustrado, de variedades, divulgava informações financeiras, cotação da Bolsa, relação de sociedades anônimas da França e do Brasil. Vale lembrar que as revistas de Charles Hu eram impressas em Bordéus, o porto de passagem obrigatória dos brasileiros em demanda da Europa ou no retorno ao Brasil. ${ }^{183}$

No rastro destes modelos de fatura francesa, emergiu um especial periodismo paulista, calcado naquelas fórmulas: muita gravura, intensa propaganda

\footnotetext{
${ }^{183}$ Revistas francesas que circularam em São Paulo, entre outras: 1887, Revue Française; 1891, France au Brésil;1892, L' Écho du Brésil; 1894, O Progresso [bilingue]; 1895, L' Éclaireure Le Buletin Français; 1901, Le Messager de Saint Paul; 1902, La Petite Revue;1902, Le Journal; 1914, Le Courrier Français e Revue de Saint Paul.
} 
e a venda da imagem do Progresso. Ou melhor, do Progresso de São Paulo. O modelo francês de revista, já aprovada até por sua tradição, inspirou os lançamentos da Capital econômica do País, que iniciava a diversificação de suas temáticas periódicas, sinalizando comunidades consumidoras e leitores específicos. Fórmula certa, mercado garantido, presidido pela padronização do gosto internacional, conforme sugeria a produção editorial francesa.

\section{"Tempos Eufóricos" ${ }^{184}$}

No compasso da virada do século, regido pelo capitalismo dos Países de economia hegemônica - então Inglaterra e França - e internacionalmente aberto às conquistas da ciência e da técnica, também o Brasil, inaugurando a nova Ordem republicana, de inspiração positivista, buscava seu lugar na modernidade do mundo. A imprensa foi o espaço onde este embate se deu com mais visibilidade. Em ritmo acelerado, das gráficas artesanais do Império passava-se à imprensa com foros de indústria, da República. Logo, o jornalismo que marcou a Primeira República foi vibrante e decisivo nos destinos do País, muito embora tenha sido neste mesmo período que aquela imprensa inaugurou vícios e mazelas que vincariam sua prática futura. Entre eles a compra da opinião da imprensa pelo governo, que se tornou rotina.

Esta fase próspera resultou da especial conjuntura vivida pelo país, definida pelo momento econômico de apogeu do café e diversificação das atividades produtivas; pela nova ordem política republicana, com programas de alfabetização e remodelação das cidades; pela agilidade introduzida pelos novos meios de comunicação; pelo aperfeiçoamento tipográfico e avanços na ilustração, enquanto as máquinas impressoras atingiam velocidades nunca vistas. A imprensa mais profissionalizada passou a figurar como segmento econômico polivalente, de influência na otimização dos demais, posto que informações, propaganda e publicidade nela estampadas influenciavam outros circuitos, dependentes do impresso em suas variadas formas. O jornal, a revista e o cartaz - veículos da palavra impressa - potencializavam consumo de toda ordem.

\footnotetext{
${ }^{184}$ DIMAS, Antonio - Tempos Eufóricos. Análise da revista Kosmos. 1904-1909. São Paulo: Ática, 1983.
} 
Todavia, a imprensa brasileira ainda estava longe de sua "fase de consolidação" como quer Juarez Bahia e mesmo da "grande imprensa", como afirma Nelson Werneck Sodré. Carlos Eduardo Lins e Silva, numa perspectiva temporal mais ampla, relativiza o avanço, ponderando: "a importação de máquinas, a adoção de técnicas, a compra de serviços de agências, a incorporação de valores do jornalismo americano são todos sinais importantes do desejo de fazer do jornal um negócio. Mas a falta de condições na economia local de sustentar essa vontade faz com que ela se frustre, embora alguns jornais consigam sobreviver (como o Jornal do Brasil e O Estado de S. Paulo, ambos inaugurados no século xix e ainda hoje entre os quatro maiores diários do país)" 185 .

Logo, o que vai permear sua trajetória é a sucessão de tempos diversos num jornalismo de modernidade contraditória. A República que se queria dos cidadãos e ávida de progresso, assentada numa economia de mercado - mas recém-saída da escravidão - espelhou as contradições da modernidade posta em contexto adverso, assistindo apenas ao engendrar da imprensa como negócio.

Tempo, espaço, velocidade e técnica potencializadas permitiram arrojo no setor, ainda que num país sem tradição editorial, mas cuja capital da República - o Rio de Janeiro cosmopolita - esmerava-se por atrelar-se à vanguarda do jornalismo; país onde, repentinamente, brotara um empório comercial vigoroso - a cidade de São Paulo e algumas capitais do país - engrenagens que punham em funcionamento os recursos viabilizadores de crescimento, testemunhados por uma imprensa vivaz.

Do telégrafo internacional — ponte invisível, que magicamente nos ligava ao "mundo civilizado europeu" - aos caminhos de ferro, tudo se mobilizava para o desfrute intenso das maravilhas do novo século, através do veículo imprensa. Naquele momento, em particular, através das revistas, gênero privilegiado em relação ao jornal, pela melhor resolução gráfica dos ultramodernos recursos visuais recém-apropriados como a zincografia e a fotografia. Para os jornais, reservava-se a linotipia, o clichê a cores e em breve, a rotogravura.

\footnotetext{
${ }^{185}$ SILVA, Carlos Eduardo Lins da - O adiantado da hora. A influência americana sobre o jornalismo brasileiro. São Paulo: Summus, 1991, pp. 63, 64.
} 
A base indispensável à sustentação da grande empresa editorial se erguia. Configurava-a, sobretudo, a adoção sistemática da propaganda e publicidade, a aplicação de capitais, a cooptação de público consumidor — representado pela emergência de uma classe média urbana —, a evolução técnica do impresso e, ainda que timidamente, os incentivos à aquisição e/ou fabricação de papel.

Para melhor apreender as conquistas quase instantâneas deste universo em franco progresso gráfico, convém repassar várias de suas instâncias, a começar pelo profissional deste novo quadro.

Entre literatos e jornalistas, a profissionalização do setor.

Com a República o jornalista ascende a postos de comando, compõe os quadros do poder, ganha outra visibilidade e se impõe como profissional. Aristides Lobo, Rui Barbosa e Quintino Bocaiúva tornam-se Ministros do novo governo.

Na sua maioria são literatos que se improvisam em profissionais da imprensa, tornando-se figuras influentes no cotidiano urbano. Paladinos da Ordem e do Progresso na República dos cidadãos, convertem-se, não raro, em agentes a serviço de grupos, classes e, sobretudo, de partidos políticos, numa imprensa que tinha o poder de tendenciosamente selecionar políticos, fazer governos, decidir eleições. Logo, o literato profissionalizou-se via jornalismo, pois havia um fato real: pagava-se! Os jornais introduziram tabelas fixas para salários, contemplando com valores substanciosos nomes de expressão no panorama político e literário.

Estava, pois, criado o mercado jornalístico, com hierarquias e tabelas de pagamento definidas. Secretário ou redator chefe recebiam os maiores salários, seguidos de redatores, repórteres e colaboradores avulsos.

A transformação da pauta deste jornalismo confinou o literato às páginas das revistas. Data, pois, deste momento a proliferação das revistas, espaço alternativo aos alijados da imprensa política. Revistas de variedades em sua maioria, em razão da segmentação ainda difusa; e fartamente ilustradas pelos novos recursos gráficos que ali apresentavam melhor resolução. 


\section{Modernidade Técnica}

A vanguarda da técnica gráfica entrara pelo Rio de Janeiro. A revista O Álbum (1893) valeu-se pioneiramente da reprodução fotográfica, colada individualmente nas páginas daquela publicação semanal; a Revista da Semana (1900) inovou ao empregar métodos fotoquímicos de reprodução.

Contudo, eram serviços caros. Levaria tempo para um jornal fazer frente às despesas de serviços fotográficos exclusivos. No tocante às ilustrações, até à pouco, secretários de redação recortavam figuras de revistas americanas para aplicá-las nas nacionais, uma vez que inexistia o amparo legal do uso da imagem. O que mais causou surpresa foi a velocidade que insistia em acelerar seu ritmo. Por volta de 1895 o periodismo diário se utilizava de uma Dilthey, que imprimia 5.000 exemplares por hora.

Em 1900, em ritmo ainda mais acelerado, o Jornal do Brasil tirava sua edição vespertina, primeiro jornal do país a lançar duas edições diárias. Imprimindo 50.000 exemplares diários, superava então o La Prensa de Buenos Aires, conhecido como o de maior tiragem da América do Sul. Em 1903, rodava 62.000 exemplares.

Mas as tiragens também aumentavam em razão do crescimento demográfico, sobretudo em São Paulo, empório comercial vigoroso, com população alfabetizada e maior poder de consumo. Em 1896, o jornal O Estado de S. Paulo que imprimia 8.000 exemplares, atingia em 1906 a tiragem de 35.000.

Decisivos na inserção internacional da imprensa, contudo, foram os serviços das agências de notícias estrangeiras, criadas em 1835 e potencializadas pelo surgimento do telégrafo, presentes no jornalismo brasileiro desde o final do século XIX. Esta internacionalização da coleta de notícias se deu no Brasil, inicialmente, através da agência Havas, que nos chegava via Portugal e completava o cartel composto pela Reuters e Wolff, modificado ao fim da Primeira Guerra, com a entrada dos Estados Unidos, através da criação da Associated Press e United Press Association ${ }^{186}$.

${ }^{186}$ THOMPSON, John B - Ideologia e Cultura Moderna. Teoria social crítica na era dos meios de comunicação de massa. Petrópolis: Vozes, 1995, p. 239. 
Letras, cores e imagens, seduzindo o novo público republicano.

Forma e conteúdo, em ritmos diferenciados, conferiram traços peculiares àquele jornalismo republicano que ensaiava a grande imprensa, avançado quanto ao tratamento gráfico, mas antigo em seu modelo editorial e no encaminhamento das matérias. As máquinas eram modernas, mas os textos e mensagens refletiam, em parte, o retrógrado quadro mental do país, de tradição escravocrata, clientelismo, partidos políticos enviesados, que faziam daquela imprensa extensão de seus próprios negócios e interesses.

No país de maioria analfabeta, a ilustração foi mais eficaz que a letra, de alcance imenso, levando-se em conta a força da imagem, decisiva para a comunicação de massa. Assim enriquecido, o periodismo potencializou-se a partir de litografias precisas, caricaturas inventivas, imagens arrebatadoras de rotogravura, ilustrações florais art-nouveau, soluções fotográficas inusitadas. Logo, formou-se o novo mercado dos chamados especialistas gráficos.

Ilustradores talentosos ganharam espaço e se converteram em profissionais requisitados. Inicialmente, através da caricatura, uma tradição de nossa imprensa, que reproduzia os desmandos da oligarquia vitoriosa. Através do humor e do chiste, criando "personagens - tipo" de grupos, partidos e classes, foi porta vOz do novo leitor cidadão.

Em São Paulo, o filho de imigrantes italianos Lemo Leni, de pseudônimo Voltolino, simboliza este segmento de agentes politizados da imagem, dos quais, inclusive, dependia o sucesso do próprio periódico. A figura do ítalo-paulista seria focalizada através de seu traço, bem como a marginalização do oprimido, numa sociedade que se estratificava de forma perversa. Mais tarde, Benedito Bastos Barreto, de pseudônimo Belmonte, iniciou na Folha da Noite sua trajetória na imprensa diária, criando o personagem Juca Pato, representação da manipulada classe média. Na paulistana A Plebe (1917), periódico anarquista, o discurso da resistência valeu-se da imagem, marcada pela vanguarda do impressionismo russo e da caricatura como recurso marcante de doutrinação ${ }^{187}$.

\footnotetext{
${ }^{187}$ CAMARGO, Dayse de - O Teatro do Medo: a encenação de um pesadelo nas imagens do periódico anarquista "A Plebe": 1917-1951. São Paulo: Mestrado em História - PUC, 1998, pp. 17 e segs.
} 
No Rio de Janeiro, o talento de J. Carlos, pondo em cena a melindrosa, imprimia em papel a elegância e a modernidade pretendidas na cosmopolita capital do País à beira-mar plantada. Na Bahia, a produção do artista Paraguaçu também confirmava a chegada da linguagem caricata moderna em Salvador.

Contudo, outro segmento de artistas plásticos de talento aderiu ao novo mercado do impresso. Eram pintores de telas que abusaram da cor nas revistas e colocaram-se em branco e preto nos jornais. O pintor Di Cavalcanti foi constante nessa atividade e Tarsila do Amaral balizou uma fase marcante do movimento modernista, via imprensa, ao ilustrar a Revista de Antropofagia (1928), com seu desenho do Abapuru.

À fotografia coube a dimensão mais abrangente como recurso de ilustração, invadindo progressivamente o periodismo. Era o recurso ideal para documentar a transformação das cidades, as cerimônias de impacto no âmbito político e social, a serviço da nova modalidade jornalística: a reportagem fotográfica. Com seu poder multiplicador — instrumento ideal para "vender" a imagem do país civilizado e moderno - a fotografia potencializou a informação, levando aos mais diversos públicos a informação até então subtraída às multidões, em especial às camadas desfavorecidas e analfabetas que configuravam o País.

Mas, lamentava-se o sepultamento dos recursos artesanais em favor da técnica, homogeneizadora e massificada. Mas o processo era irreversível: redações e jornais das capitais aparelhavam-se com tecnologias de ponta, com vista à comunicação de massa.

\section{Criando um mercado de leitores}

Incremento da produção, adensamento de população, desenvolvimento da comunicação e processo de urbanização acelerado fizeram-se acompanhar de uma diminuição da taxa de analfabetos. Afinal, na jovem República, a erradicação do analfabetismo se colocava como prioridade no país que pretendia formar cidadãos. Não obstante, por volta de 1890, ainda 80\% da população não sabia ler. Para seu combate disseminou-se, sobretudo nas capitais do Sul, uma rede de Grupos Escolares de iniciativa oficial, regidos pela proposta do ensino livre, universal e gratuito, resultando na diminuição da taxa de analfabetismo; 
longe, porém de atingir os níveis desejados. Nada estranho que, hoje, localizem-se nestes estados - São Paulo e Rio de Janeiro — os maiores conglomerados da imprensa do País.

Ao lado do "saber ler" da República, se colocou a necessidade de formar leitores - consumidores. Com forte cunho mercadológico, valendo-se de um nicho de mercado da época, foi lançado no Rio de Janeiro Eu sei tudo (1917); também neste propósito, a revista Vamos Ler (1936), títulos periódicos de sucesso de público, cópias de publicações francesas, que circularam por anos a fio e formaram gerações afeitas ao consumo do livro, da revista e do jornal. Neste momento, como estratégia de mercado consumidor, iniciou-se a conquista do leitor infantil, através de uma revista de sucesso e lendária na memória de gerações, O Tico-Tico (1905), que se manteve por 50 anos.

Por outro lado, as grandes levas de imigrantes que engrossaram cidades brasileiras ampliaram consideravelmente a prática da leitura, a produção e consumo de periódicos. Em São Paulo, circularam mais de 500 títulos de periódicos étnicos, muitas vezes de redação bilíngüe. Na sua maioria eram títulos da comunidade italiana, figurando também folhas de grupos espanhóis, alemães, ingleses, franceses, libaneses e japoneses. Neste segmento da produção de imigrantes, destacou-se o jornal semanário domingueiro da comunidade italiana Fanfulla (1893) que se transformou em diário, como o alemão Deutsche Zeitung, (1897).

Concomitantemente, nas cidades de industrialização crescente e força operária expressiva assistiu-se ao florescimento da imprensa libertária, representada, sobretudo, pelos jornais e revistas anarquistas, anarcosocialistas, socialistas e comunistas. Muitos circularam na clandestinidade, mas criaram públicos próprios e desempenharam papel doutrinador, difundindo práticas culturais valorizadas pelos movimentos de esquerda: leitura, cultivo do teatro, difusão de jornais propagadores de seus programas e ideais, veiculação de doutrinadores teóricos.

\section{Propaganda e Publicidade: tudo pelo comércio}

Ao contrário da propaganda, de caráter ideológico, contemporânea do próprio surgimento da imprensa, a publicidade nasceu no quadro desencadeado pela concorrência capitalista empresarial, com a conseqüente formação de 
boldings e a acirrada competição em curso. "Faça publicidade ou se arrebente", passou a ser o slogan fatal e verdadeiro. Ambas passaram a atuar como mecanismo crucial dos quadros de demanda, decisivo na conduta social do iniciante século XX.

No Brasil, a propaganda de ordem política foi recorrente na imprensa local, quando a criação de jornais praticamente se restringiu ao fortalecimento de partidos e grupos políticos. Mais ostensiva, ainda, na imprensa da Primeira República. Campos Salles, por exemplo, publicou a obra Da Propaganda à Política, onde procurava justificar a postura político propagandística de seu governo; a Campanha Civilista, em 1909, liderada pelas facções de Rui Barbosa e Hermes da Fonseca, consolidou o jornalismo da propaganda política, tradição de nossa imprensa.

Quanto à publicidade, beneficiou-se em seguida de recursos visuais que divulgavam produtos e prestavam serviços. Neste momento, em termos de periódico, mais uma vez a revista foi veículo dos mais efetivos.

Entre os gêneros de ilustração em voga, a caricatura passou a ser dominante nas campanhas, recurso ideal, fosse pela fácil leitura da mensagem, independente de legenda, como pelo clima de circunstância, ritmada com o episódico, com a natureza e dinâmica do periodismo.

Tornou-se de tal forma o suporte ideal que, em sua essência, quase se confundia com ela, uma vez que ambas, revista e publicidade, direcionavam-se para o mesmo propósito: dar-se a conhecer, divulgar-se, "produzir-se para vender-se". A revista, pois, era a publicidade; ou por outra, no periodismo da época, a revista transformou-se na embalagem ideal para o produto publicidade.

No pós-Primeira Guerra (1914-1918) o uso de recursos sensoriais foi decisivo para conquista do consumidor. Imagem e texto ritmados, versos em redondilha, com apelos do momento foram recorrentes, estampando-se a imagem de força através dos símbolos da guerra (capacetes, tanques); ou da velocidade (avião); ou da saúde e higiene (corpo musculoso, sugerindo sucesso) ou da internacionalização (zepelins).

As mensagens veiculadas pela propaganda e publicidade passaram a conformar a mentalidade do período, tarefa estimulante numa sociedade em transformação, dividida entre a valorização das origens, da tradição e a incorporação de modelos estrangeiros, veiculados sistematicamente pela imprensa. O periodismo 
transformou-se em desaguadouro dessa propaganda e/ou publicidade, enquanto passava a depender das encomendas publicitárias de comerciantes, leiloeiros, cinematógrafos, empresas teatrais e cinematográficas, casas de patinação, firmas de importação, casas comissárias, enfim, de tudo que as cidades experimentavam de "novo" e precisava ser colocado no mercado.

A revista entre o jornal e o livro.

Com a República, a imprensa potencializa-se com "literatos profissionais" em busca de mercados, técnicas otimizadas pelos recursos modernos, público leitor ampliado em razão do aumento da população, agora significativamente alfabetizada e poder aquisitivo favorecido pela emergência de camadas urbanas escolarizadas.

A revista, na sua modalidade específica de impresso ligeiro, beneficiou-se largamente dessa circunstância literária, técnica e mercadológica, desde que, submetida às suas regras. Permitiu o abuso da literatura a serviço da reportagem e, precedendo o jornal, resultou em veículo para experimentos da modernidade técnica. Com uma diferença do periodismo pregresso, pois proliferou em outras mãos: as de homens de mercado, que faziam da revista seu negócio.

A necessidade de estabelecer diálogos efetivos entre autor e público, para garantir o sucesso econômico do impresso, determinou concessões de parte a parte. Tanto do escritor, que se propunha a escrever em qualquer periódico que lhe desse espaço, como do editor, que reunia nomes vendáveis, independente de suas afinidades temáticas ou ideológicas, para garantir o consumo do produto.

E mais: se o jornal confinara-se ao trato das questões políticas, ficando ainda a desejar quanto à resolução gráfica dos avanços técnicos mais sofisticados, a revista, ainda que semanal, permitia confecção apurada através dos experimentos gráficos modernos que as tornavam atraentes, dotadas de apelo lúdico sedutor. Por outro lado, no país sem tradição livreira, isento de editoras nacionais que barateassem o produto livro, coube à revista receber textos da produção literária da hora, abrigando nossa melhor literatura. O alto custo do livro, na República nascente, em geral importado, acabou por preteri-lo em favor da revista. Acrescente-se, ainda, as facilidades para abertura de um magazine, 
na época, sem as demandas burocráticas e administrativas comuns às empresas de hoje, permitindo que muitos títulos proliferassem, ainda que de duração efêmera, acometidos do famoso "mal dos sete números".

Logo, o periódico revista foi o suporte gráfico preferencial entre o jornal e o livro, produto de aquisição até módica, fosse nas charutarias dos Cafés ou mesmo através do serviço de assinaturas, esse também ensaiando naquele impresso, as modernas formas de venda, do envio gratuito de um exemplar para apreciação do possível cliente à utilização do recurso dos brindes, que acompanhavam algumas coleções.

A contribuição paulista teve peso quantitativo e qualitativo, comparecendo com maior produção periodística segundo a posição geográfica. Em 1912, São Paulo era o primeiro colocado, com 341 periódicos e o Rio Grande do Sul, o segundo colocado com 124; em 1930, São Paulo repetia a liderança com 706 periódicos, seguido do Distrito Federal, com 524.

Revistas de todo o teor: intérprete de utopias

Nas volúveis chamadas de capa ocorriam mudanças freqüentes, presididas pela "mera intuição" de novo segmento consumidor, ou pela viabilidade de propostas temáticas alternativas submetidas, sobretudo, aos modismos sugeridos pelos periódicos estrangeiros.

O subtítulo variedades e ilustradas encontrava-se na maioria delas, como apelo conotativo de sua atualidade, garantindo o interesse do consumidor, ávido da informação ligeira, diversificada e, acima de tudo, ilustrada. Embora esses atributos caracterizassem aquele periodismo, tão afinado com o espírito da belle époque, configurando historicamente uma nova tipologia de publicação, essa abrangência impossibilita o recorte específico das revistas de variedades e daquelas ilustradas.

De variedades, praticamente todas o eram, ainda que agrícolas, esportivas ou femininas e tantas, pois em seu interior os assuntos e as seções se diversificavam para agradar ao respectivo público alvo e aquele que poderia ainda conquistar; ilustradas, nem todas, fosse pelas exigências de recursos mais elevados, ou conhecimento técnico específico. No geral, contudo, a produção se valeu do uso da imagem, na sua maioria sob tratamento fotoquímico. 
Da mesma forma, as revistas literárias, indiscriminaram-se e confundiram-se com aquelas de tipologias específicas. Ou melhor, a literatura se colocou em todo o periodismo da época, dado o vezo daquela geração, às voltas com poesia, prosa e muita paixão. Na sua maioria anunciavam propósitos literários, mas em seu interior apresentavam, sobretudo, ilustrações, notas sociais, crítica ou exaltação política, a infalível crônica e algum soneto. Diga-se que a sobrevivência de uma revista literária stricto sensu revelou-se então inviável, como se inferiu da Revista Literária, de 1895, dirigida por Amadeu Amaral e Maximo Pinheiro Lima, secretariada por Luís Carneiro ${ }^{188}$. Não obstante a colaboração de Zalina Rolim, Francisca Júlia, Escragnole Dória, Garcia Redondo, Júlio César da Silva, Valdomiro Silveira, Henrique de Barcelos e outros, o periódico desapareceu já no primeiro ano de vida, vítima de todos os males que acometiam empreendimentos extemporâneos em relação às demandas e/ou mercados: falta de público, improviso da iniciativa, precariedade de administração, irregularidade dos colaboradores, mais ainda por tratar-se de periódico semanal.

Quanto ao humor, se fez presente em grande parte daquela produção, sobretudo na quadra 1908-1930, com as figuras da oligarquia, disseminando-se por toda produção revisteira ${ }^{189}$.

Notável, ainda, o elenco de revistas étnicas, na maior parte em língua italiana. Assim como as publicações afetas às minorias e/ou comunidades de apreço relativo, naquele contexto. Embora com escopos diversos, podem ser incluídas na mesma chave as ditas carnavalescas e as pornográficas. As primeiras, vindo a público por ocasião das festas de Momo, sem constância de circulação, evidenciando a necessidade de quebra de normas da conduta padrão.

Quanto às segundas, a incidência foi restrita, em geral de pouca criatividade, de concepção grosseira, longe de algum exemplo como aquele d' $A$ Maçã, a especial publicação carioca, de conteúdo picante. Revistas espíritas e mesmo maçônicas, foram registradas com razoável número de títulos, de análise complexa, pela especificidade de seus temas.

\footnotetext{
${ }^{188}$ Revista Literária, publicação semanal. São Paulo: no 7 (1895).

${ }^{189}$ GALLOTTA, Brás Ciro - O Parafuso: humor e crítica na imprensa paulistana. 1915-1921. São Paulo: Mestrado, PUC, 1997
} 
A reprodução do quadro de classificação da época, a seguir, é oportuna, em que pese a "possível" inexatidão numérica dos dados, seja pela relativa precariedade da produção periodística da época, e/ou dificuldade de coleta de informações pelo então Departamento Nacional de Estatística.

Várias são as ilações sugeridas por esses números, que podem ser trabalhados consoante o interesse de cada leitor. A fonte é particularmente rica de informes acerca da evolução de tendências temáticas, possibilitando alguns balanços. Significativo, de pronto, o aumento de publicações religiosas, com mais de 188 títulos entre 1912 e 1930, em detrimento das literárias, com crescimento no mesmo período da ordem de mais de 79 títulos, em tempos de República que se pretendia laica. Notável o aumento das publicações científicas, que de um total de 58, em 1912, passaram a 212, em 1930, expressando a ampliação do quadro institucional científico que a República positivista procurou estabelecer; e o sintomático declínio das publicações de iniciativa maçônica que perdiam terreno. Declínio, que também deve ser visto com reservas, pois esses números podem decorrer, como já sugerido, da omissão nas informações da época e/ou deficiência na coleta de dados. 
QUADRO IX: PRODUÇÃO PERIODÍSTICA DO BRASIL: 1912-1930

\begin{tabular}{|c|c|c|c|c|}
\hline NATUREZA & 1912 & 1930 & DIFERENÇA & PORCENTAGEM \\
\hline Noticiosos & 882 & 1.519 & +637 & $+72,2$ \\
\hline Literários & 118 & 297 & +79 & $+151,2$ \\
\hline Religiosos & 84 & 272 & +188 & $+223,8$ \\
\hline Científicos & 58 & 212 & +154 & $+265,5$ \\
\hline Humorísticos & 57 & 99 & +42 & $+73,6$ \\
\hline Comerciais & 23 & 82 & +59 & $+256,5$ \\
\hline Anunciadores & 19 & 72 & +53 & $+278,9$ \\
\hline Almanaks & 14 & 66 & +52 & $+371,4$ \\
\hline Esportivos & 5 & 58 & +53 & $+1.060,0$ \\
\hline Corporativos & & 48 & +48 & \\
\hline Oficiais & 21 & 44 & +23 & $+109,5$ \\
\hline Agronômicos & 23 & 34 & +11 & $+47,8$ \\
\hline Didáticos & 8 & 33 & +25 & $+312,5$ \\
\hline Estatísticos & 11 & 29 & +18 & $+163,6$ \\
\hline Espíritas & 22 & 21 & -1 & $-\quad 4,5$ \\
\hline Históricos & 7 & 14 & +7 & $+100,0$ \\
\hline Militares & 6 & 11 & +5 & $+83,0$ \\
\hline Industriais & 2 & 11 & +9 & $+\quad 450,0$ \\
\hline Infantis & 1 & 11 & +10 & $+1.000,0$ \\
\hline Cinematográficos & & 10 & +10 & \\
\hline Maçônicos & 10 & 7 & -3 & $\begin{array}{l}-\quad 30,0 \\
\end{array}$ \\
\hline Marítimos & 3 & 6 & +3 & $+100,0$ \\
\hline Filosóficos. & 3 & 3 & & \\
\hline TOTAL & 1.377 & 2.959 & +1.582 & $+114,9$ \\
\hline
\end{tabular}

FONTE: Estatística da Imprensa Periódica no Brasil. Rio de Janeiro: Typ. do Departamento Nacional de Estatística, 1931, p. IV.

O surgimento das revistas corporativas, praticamente inexistentes em 1912, e totalizando 48 títulos, em 1930, confirmava a especialização profissional e a estratificação social decorrentes da nova força de trabalho. Inegável a potencialização do comércio, se considerarmos em conjunto as revistas ditas comerciais e anunciadoras, essas em particular, revelando o avanço da propaganda, em função da necessidade de ampliação do mercado consumidor.

A descoberta do filão do periodismo infantil — registrando-se apenas uma em 1912 e totalizando 11 títulos em 1930 - , perfazia juntamente com as revistas 
esportivas o maior crescimento do mercado periodístico, da ordem de mais de $1.000,0 \%$ e mais de $1.060,0 \%$, respectivamente.

Os dados do impresso pertinentes à indústria sinalizavam progressão da ordem de 450,0\%, enquanto o setor agrícola, de fundamental importância para o País, resultava em crescimento modesto, da ordem de 47,8\%. No caso de São Paulo, é lícito aventar uma justificativa para a tímida porcentagem das revistas agronômicas. As primeiras publicações desse segmento, geralmente de iniciativa oficial ou capitaneadas por um grupo editorial de peso, não permitiram, de imediato, a criação de congêneres que competissem no mercado. As poucas existentes monopolizavam a matéria e a liderança das assinaturas. O Boletim Agrícola [1900] e a Revista Agrícola [1906], empreendimentos do governo, criaram público cativo, dada sua gratuidade. Já O Fazendeiro [1907] e mais tarde a vitoriosa Chácaras e Quintais, absorveram o público leitor, respondendo durante muitos anos por essa fatia do mercado de periódicos, preferência acentuada do consumidor paulista.

A substituição do teatro pelo cinema é confirmada pela total ausência de revista cinematográfica em 1912 e o registro de 10 revistas do gênero, em 1930.

Infere-se, pois, a abertura do século xx paulistano com mercado periódico de revistas em potencial, representativo da já diversificada segmentação de seu público, revelando práticas e comportamentos de grupos sociais, econômicos, ideológicos, religiosos, sindicais, femininos, pedagógicos, profissionais, étnicos, infantis e até carnavalescos, gama expressiva de que então se constitui a emergente sociedade paulistana, ávida de representação. A revista foi a intérprete fiel de suas demandas e, mais que isso, de seus sonhos, projeções e utopias.

Nesse sentido, podemos arrolar como mais presentes, as revistas que tratavam de temas caros à República, figurando seus exemplares como documentos favoráveis à percepção de sua imagem e das temáticas eleitas. Bloco expressivo foi o das revistas agrícolas, de importante demanda no País rural. Em seguida, as pedagógicas, tema caro à Republica semi-implantada. Na seqüência, as institucionais, de cunho laico; as esportivas que conheceram maior sucesso mercadológico; as religiosas que encetaram os respectivos proselitismos; as femininas, ampliadas pelas iniciativas da nova mulher; as teatrais, em transição para as cinematográficas; a emergente revista infantil e, finalmente, a produção paralela à imprensa burguesa, aquela da revista operária. 
No caso de São Paulo, não obstante muitos destes segmentos representarem-se por edições de efêmera duração, sua emergência, por si só, prenunciava a existência de grupo social, profissional ou cultural de relevo no mercado. Mais do que apontar as tendências do impresso periódico, as tipologias das revistas acabaram por enunciar as múltiplas dimensões da sociedade paulistana.

Até então, a crítica política nas revistas comerciais ficava por conta dos caricaturistas. O público leitor ainda difuso, não permitia uma segmentação precisa, que se verificou, sobretudo, a partir dos anos de 1930.

É hora de finalizar. Para isso, escolhemos uma revista ícone dos tempos eufóricos republicanos, uma das melhores representações da pretendida imagem do país que se "civilizava” com a República.

Trata-se da revista Kosmos, na Capital da República ${ }^{190}$. Emblemática no gênero, de rico projeto gráfico, lançada em 1904, no calor dos preparativos para construção da Avenida Central, no Rio de Janeiro, hoje é citada à exaustão para evocar o período. Afirmar que Kosmos retrata o cotidiano do projeto O Rio Civiliza-se, do qual é contemporânea, que sua impressão é de alto nível e que, portanto, dá conta de revelar o estágio técnico atingido por nossas gráficas - é muito pouco. A apreciação denota que se embarcou tão só na sedução das imagens aliciantes, ignorando sua mensagem a serviço de um projeto político e econômico, generalizando o entendimento de um periódico que, a despeito de publicar contos, poesia e crítica, não era uma revista literária.

Em boa hora, essa publicação foi objeto de estudo criterioso por parte de Antonio Dimas ${ }^{191}$, inferindo que a publicação esteve a serviço, e talvez até tenha surgido como porta-voz do programa de modernização de Rodrigues Alves, caro aos republicanos históricos. Não obstante sua análise abrangente, o próprio autor admite não obter elementos de comprovação material dessa ligação — poder

\footnotetext{
190 "Kosmos". Rio de Janeiro: 1904. Num total de 64 números, foi dirigida por Mário Behring por 16 meses quando passou à direção e propriedade de Jorge Schmidt [1870-1926]. Este, tendo estudado em Londres e na Bélgica,conhecendo as revistas de lá e como proprietário de uma tipografia na rua da Assembléia, amigo de literatos e jornalistas, fundou Kosmos. Cara para a época, (20\$000 anual), voltava-se para intelectuais. De grande formato (31 x 25), vinha impressa em papel couché, a cores, muitas ilustrações, diagramação sofisticada com predomínio de art-nouveaux. Compreendia seções de prosa, poesia, crítica, história, sociologia, geografia, matemática, noticiário, publicidade, diplomacia, matéria militar e muita ilustração. Escreviam: Medeiros e Albuquerque; Olavo Bilac; Artur Azevedo; Lauro Müller, Alberto de Oliveira; José Veríssimo; Oliveira Lima; Afonso Arinos; Manoel Bonfim; Gonzaga Duque, entre outros. Ilustrações: Rodolfo Bernardelli; Marc Ferrez; F. Soucaseaux; Guilherme Gainsly.

${ }^{191}$ DIMAS, Antonio - Tempos Eufóricos, op. cit.
} 
e periódico - no plano de uma confirmação mecânica; e aí, inferimos nós, exatamente porque o conluio entre poder e editor era de tal ordem, que o produto vinha muito bem embalado, na ordem natural das coisas. Apontando para a mensagem dupla da revista, isto é, espaço de representação de grupo e veículo de propaganda da administração Rodrigues Alves/Pereira Passos, Dimas conclui:

"Como espelho polido de um período que se queria moderno, Kosmos carregava no bojo suas próprias contradições. Se a época era de trabalho, de labuta, convinha desmascarar certos preconceitos arraigados como o da fatuidade da classe diplomática, por exemplo"192.

Propósito frustrado, pois as próprias imagens reproduzidas em couché acabavam por constituir-se em mostruário da elegância ociosa que marcava o cotidiano da elite. A percepção de Dimas em outro âmbito foi reforçada pelo registro arguto do escritor Lima Barreto, no papel de advogado do diabo, captando e destilando com sutileza o engodo inerente ao projeto civilizador. Em carta de 13 de Julho de 1905 a Gregório Fonseca, Barreto revelava o artificialismo do cenário em relação ao possível aproveitamento de elementos construtivos genuinamente brasileiros, reveladores de nossa paisagem, personalizados ao contexto local.

"Ontem inaugurou-se a avenida Stá bonita; cheia de canteirinhos, candelabros, etc; mas os edifícios são hodiondos, não que sejam feios. Ao contrário, são garridos, pintadinhos, catitas; mas lhes falta para uma rua característica de nossa pátria, a majestade, a grandeza, acordo com o local, com a nossa paisagem serena e mística. Calculas tu que na cidade do granito, na cidade dos imensos monolitos do Corcovado, Pão de Açúcar, Pico do Andaraí, não há na tal avenida-montra um edifício construído com esse material. Choveu a mais não poder, assim mesmo ela esteve cheia, de tropa e de povo"1193 [sic].

O empanar da realidade, divulgando-a conforme os interesses de classe, grupos e indivíduos, é vezo desse periodismo triunfante que, naquela virada do século, poten-

\footnotetext{
${ }^{192}$ Ibidem, p. 136

${ }^{193}$ BARRETO, Lima - Marginália. Rio de Janeiro: Editora Mérito S/A, 1953.
} 
cializado pelos recursos da propaganda e publicidade, tornou-se instrumento preferencial a serviço das relações capitalistas que permeavam a sociedade como um todo.

A sinalização adequada e preventiva para análise das demais publicações do período, vem novamente das palavras de Antonio Dimas, em sua análise de Kosmos:

"Da leitura integral de Kosmos o que emerge, em última instância, é o exemplo concreto de um tempo dilacerado e ambíguo. Kosmos é casca vistosa de modernidade que queria impor-se à custa de notícias ficcionalizadas como recurso de abrandamento; de concessões regionalistas alambicadas; de cronistas empenhados, mas cautelosos; de poesias moralizantes e edificantes, tudo isso envolto em vinhetas florais. A representação do momento encontrara excelente signo: a flor, que o Art Nouveau nos exportara. Mais uma vez o mito cumpria a função de "evacuar o real". A flor cheira, embeleza e purifica o ambiente"194.

Ou seja: tudo ficava muito bem disfarçado. Desmontado o ideário vendido pelo periódico, revela-se o quanto suas páginas higienizadas, de um Itamarati e de uma população brancas, estavam longe de retratar o cotidiano sofrido de um País analfabeto, atrasado e arcaico.

A recuperação de um libelo indignado na revista literária paulista Iris, de 1905, é esclarecedor dos comprometimentos dessa "indústria" ao seu tempo, percebido e combatido pela crítica coeva, que denunciava a submissão do periodismo aos anseios da opinião pública:

"O jornalismo que se faz indústria, longe de guiar e esclarecer a opinião, procura inspirar-se nela, sonda precatadamente suas tendências afaga seus gestos, anima suas inclinações, corteja seus pendores, acaricia-lhe — quantas vezes! - as aberrações mórbidas repulsivas, acovarda-se, achata-se, anula-se, dissolve-se, num apagamento de critério, numa obliteração de vergonha. Mas "[...] não perde o leitor de todo o dia, ofreguez da mofina, o freguez dos anúncios, o freguez dos editais".

No campo da estética, na arena da política, no domínio da moral, semelhante jornalismo não quer ter, não pode ter e não tem opinião própria, opinião redatorial, opinião responsável; esposa a média das opiniões de todo o mundo, pensa como todo o mundo e assim é lido por todo mundo.

${ }^{194}$ DIMAS, Antonio - Tempos Eufóricos, op. cit., pp. 136, 137. 
"[...] O povo deleita-se com esta leitura desproveitosa e nociva, justamente porque as folhas são feitas a sua imagem e semelhança, porque elas o reproduzem com todas as suas impurezas e todas as suas paixões.

[...] Os artigos de polêmica e de combate, os artigos de doutrinação e de política, os artigos de interesse comum relativos a questões econômicas, os artigos literários, as crônicas de arte e as crônicas de sport, a crítica, o verso, as diferentes seções, finalmente, são feitas pelo contingente dos colaboradores generosos, que não representam nunca a opinião dos jornais em que trabalham. $\hat{E}$ - como se vê - uma inversão total de postos e de funções" ${ }^{\prime 195}$.

Infere-se que a procedência e formação do articulista inscrevem-se num projeto nacionalista, debatendo-se pela construção qualificada da República, que estava longe de pensar, efetivamente, a Res Publica. Confirmava a produção dos escritos da imprensa a serviço de órgãos dependentes, encobrindo o registro espontâneo e a verdadeira opinião do jornalista, com o fim último de não perder o freguês.

Traços muito peculiares, portanto, vincam esse periodismo que se profissionalizava e se conscientizava de seu poder, ensaiando a entrada na grande imprensa. Nesse propósito percorremos um pequeno, mas significativo trecho de sua trajetória, atentos ao sentido de mão dupla deste percurso, por vezes na contramão, com vistas a iluminar parte recôndita do passado.

Viu-se que a idéia de República encontrou abrigo em nossa imprensa, desde seus primeiros passos. Uma vez na ordem republicana, coube às revistas de variedades, a melhor representação do quadro mental do período, expresso em suas páginas de textos parnasianos arrebatados e imagens fulgurantes, projeções impressas de um tempo político cultural.

Considerando o aporte da propaganda naquelas publicações, enfeitando uma realidade em tudo avessa ao sonhado pelos liberais, não seria demais lembrar, com Chesterton, que jornalista é aquele que escreve no reverso dos anúncios, ou com McLuhan, que a notícia é um bem de consumo e por isso carrega com ela a publicidade ${ }^{196}$, manipuladora de percepções e vontades.

\footnotetext{
195 "Iris: Revista Mensal de Letras, Ciências e Artes". São Paulo: Tip. Andrade \& Mello, ano I, n¹ (Nov. 1905), pp.16,17.

${ }^{196}$ Apud GALVÃO, Walnice N. - No Calor da Hora. A Guerra de Canudos nos Jornais. São Paulo: Ática, 1977, p. 15
} 


\section{Bibliografia}

ADORNO, Sérgio - Os aprendizes do poder. O bacharelismo liberal na politica brasileira. São Paulo: Paz e Terra, 1988.

AUMONT, Jacques - A Imagem. Campinas: Papirus, 1993

BALANDIER, George - O Poder em Cena. Brasília: Editora da UnB, 1982.

CAGNiN, Antonio Luiz - "Diabo Coxo: o primeiro jornal ilustrado de São Paulo". DO Leitura. São Paulo: Imprensa Oficial do Estado, Out. 1994, 13 [149]

CARNEIRO, Maria Luiza Tucci - Livros Proibidos, Idéias Malditas. O Deops e as minorias silenciadas. São Paulo: Estação Liberdade, 1987.

DAVIS, Natalie Zenon - "O povo e a palavra impressa". In Culturas do Povo - sociedade e cultura no início da França Moderna. Rio de Janeiro: Paz e Terra, 1990.

DIMAS, Antonio - Tempos Eufóricos. Análise da revista Kosmos. 1904-1909. São Paulo: Ática, 1983.

GALLOTTA, Brás Ciro - O Parafuso: bumor e crítica na imprensa paulistana. 1915-1921. São Paulo: Mestrado, PUC, 1997

GAlvãO, Walnice N. - No Calor da Hora. A Guerra de Canudos nos Jornais. São Paulo: Ática, 1977.

JANOTTI, Maria de Lourdes Mônaco - Os subversivos da República. São Paulo: Brasiliense, 1986

KOSSOY, Bóris - Origens e expansão da fotografia no Brasil - século XIX. Rio de Janeiro: Funarte, 1980

LAJOLO, Marisa - A formação da leitura no Brasil. São Paulo: Ática, 1996

LUCA, Tania Regina de - A Revista do Brasil: um diagnóstico para a [N]ação. São Paulo: Editora Unesp, 1999.

LUSTOSA, Isabel - Insultos impressos. A guerra dos jornalistas na Independência. 1821 - 1823. São Paulo: Companhia das Letras, 2000.

MARTINS, Ana Luiza - Revistas em revista: imprensa e práticas culturais em tempos de República. São Paulo: Edusp; Fapes; Imesp, 2001.

Idem - Gabinetes de Leitura da Província de São Paulo: a pluralidade de um espaço esquecido. São Paulo: Mestrado História USP, 1990.

Idem; DE LUCA, Tania - Imprensa e cidade. São Paulo: Editora UNESP, 2006.

Idem; BARBUY, Heloisa - Arcadas. História da Faculdade de Direito da Universidade de São Paulo. São Paulo: Alternativa/Melhoramentos, 1999.

OLIVEIRA, Lúcia Lippi - A Questão Nacional na Primeira República. São Paulo: Brasiliense, 1990.

PRADO, Antonio Arnoni [org.] - Libertários no Brasil. Memórias, Lutas, Cultura. São Paulo: Brasiliense, 1986

SEVCENKO, Nicolau - Literatura como Missão. Tensões e criação cultural na Primeira República. São Paulo: Brasiliense, 1983.

SILVA, Carlos Eduardo Lins da - O adiantado da bora. A influência americana sobre o jornalismo brasileiro. São Paulo: Summus, 1991.

SODRÉ, Nelson Werneck - História da Imprensa no Brasil. Rio de Janeiro: Civilização Brasileira, 1966 
SUSSEKIND, Flora - As Revistas de Ano e a Invenção do Rio de Janeiro. Rio de Janeiro: Nova Fronteira/ Fundação Casa de Rui Barbosa, 1986.

THOMPSON, John B. - Ideologia e Cultura Moderna. Teoria social crítica na era dos meios de comunicação de massa. Petrópolis: Vozes, 1995.

VELLOSO, Mônica Pimenta - A brasilidade verde-amarela: nacionalismo e regionalismo paulista. Rio de Janeiro, CPDOC (Textos CPDOC), 1985.

VOVELLE, Michel - Ideologias e mentalidades. São Paulo: Brasiliense, 1987.

Idem - Imagens e imaginário na história; fantasmas e certezas nas mentalidades desde a Idade Média até o século XX. São Paulo: Editora Ática, 1997. 